\title{
The Education Quality of State Junior High School
}

\author{
Riswanti Rini, Agustina \\ FKIP \\ Universitas Lampung \\ Lampung, Indonesia \\ riswanti.rini@gmail.com
}

\begin{abstract}
The research was aimed to find out the education quality of Junior High School in Terbanggi Besar district based on school's principal leadership and teacher performance variable. The method used was quantitative descriptive. The population of this study was Junior High School teacher in Terbanggi Besar district, Central Lampung regency as many as 122 people, the samples used was proportional random sampling as many as 93 people. The data were collected through questionnaires and data analysis technique used was regression. The conclusion of this research was the education quality of Junior High School in Terbanggi Besar district in terms of the school's principal leadership and teacher performance variable has influenced the education quality.
\end{abstract}

Keywords-leadership, performance, education quality

\section{INTRODUCTION}

According to the Education for All (EFA) in Global Mentoring Report, the education quality has two main principals, the first is to identify the cognitive development of the students as the goal which contained in the whole education system, the second is to emphasize the role of education in promoting values and responsibility attitudes of the citizens in developing the creativity and emotional growth [1].

The advancement of education could not be separated from the education quality. Education is very important, especially in the national welfare. Therefore, the national education standard has an aim to ensure the national education quality in order to educate the nation and form the character and the civilization of the nation's dignity. In order to reach the goal stated before, the government has established the regulation number 19 year 2005 related to the National Education Standard (PP No.19 Tahun 2005), in which there are eight standards that must be fulfilled to implement the education. The eight standards may include the standard of content, process, competency of the graduates, educators and education staff, facilities and infrastructure, management, financing and assessment.

One of the standards which was considered directly related to the education quality was competency standards of graduates. Competency standards of the graduates as national education standards for the qualifications of graduate's abilities related to knowledge attitudes and skills [2]. One which is related to the quality of graduates which had been determined by the government was national examination, because basically the national examination was an instrument in controlling the national education quality, fostering the increasing of the education quality, even in determining the graduation of the students and as the consideration in selecting the new student's admission at a higher level. The function of national examination was not different with the opinion of the experts, for example, stated that the final test is for certification, selection, survey and quality control of education [3]. So that the functions can be run properly, the final examination is a systematic process to collect, analyze, and interpret, in order to determine the extent of the achievement level of the students towards the learning objectives [4]. Thus the function of the test is intended to determine the effectiveness and the level of achievement or success of a teaching program [5].

The important factor to improve the education quality is the school principal leadership. In his book, Your Child's Scholl, there are ten determinant factors in realizing the good education process, one of them is the school principal leadership [6]. The school principal played a key role in moving the organization of the school. The principals who could carry out their duties well enough would affect the education quality. The school principals who were able to carry out their roles and functions as EMASLIM would improve the teacher's performance and also could improve the education quality [7].

The forefront of the quality of education improvement is the teacher, therefore the education quality cannot be separated from the conditions of teachers as one element of education. Teacher has a responsible for educating, teaching and guiding the students. The responsibility of a teacher must have the ability to design the learning programs and be able to organize and manage the classroom so that the learners can learn and can eventually reach the level of maturity as the final goal of the educational process.

From the background above, the researcher proposed the following issues, such as what kind of education quality viewed by the variables of school's principal leadership and teacher performance. As an effort to develop the education management field and to explain in detail and systematically about the improvement of education quality, especially in Central Lampung.

Leadership and changes in school management is the leadership behaviors that had emphasized the changes. In other words, if the leader helped in creating the goals, policies, or structures, and new procedures, he showed the leadership behavior. This means that there is a need for leaders to equip themselves with the knowledge and leadership skills to design, advise, and bring in innovations in education and 
administration with stems to a realistic assessment of current practices and based on good ideas about management processes [8]. The school principal leadership which is discussed here is the leadership in role and function as educator, manager, administrator, supervisor, leader, motivator, and innovator [7].

Define performance as a behavioral assessment that fundamentally include the quality of work, the quantity of work, the knowledge of work, the opinions or statements which are delivered, the decision taken, the work planning and the area of the work organization [9]. If the performance is the quality and quantity of work that can be done by a person, then the performance is the output of the task execution. Performance is closely influenced by the productivity as an indicator in determining how the efforts to achieve a high level of productivity in the organization.

\section{METHOD}

The method used was quantitative descriptive. The study population was Junior High School teacher in the Terbanggi Besar district, Central Lampung regency as many as 122 people, the samples used was proportional random sampling as many as 93 people. The data were collected through questionnaires and data analysis technique used was regression.

\section{RESULTS AND DISCUSSION}

\section{A. School Principal's Leadership}

Based on the calculation result, it obtained that $t_{\text {count }}$ of school principal's leadership is 6,658 and $t_{\text {table }}$ is 1,990 ; so that $\mathrm{t}_{\text {count }}<\mathrm{t}_{\text {table }}$ or $6,658<1,990$, it means that $\mathrm{H}_{0}$ is rejected and $\mathrm{H}_{1}$ is accepted, meaning that the education quality viewed by the school principal's leadership variable has a positive and significant influence. It showed that by the existence of good principal, then the principal is able to interact with the environment in influencing or convincing the teachers to cooperate with the school principal as a team to achieve the school's objective. The leadership factor would determine and influence the level of the teacher's performance which was achieved as a result of the execution of its duties and functions assigned. In the knowledge of leadership, then duties and functions of the principal as a leader could be implemented and executed directionally and easily.

\section{B. Teacher Performance}

From the calculation result, it obtained that tcount of teacher performance is 4,631 and ttable is 1,990; so that tcount $<$ ttable or $4,631<1,990$, it means that $\mathrm{H} 0$ is rejected and $\mathrm{H} 1$ is accepted, meaning that the education quality viewed by the teacher performance variable has a positive and significant influence. The education quality cannot be separated from the conditions of the teachers as one element of education. The teachers have a position and a very important role in the overall strategic effort to achieve the education quality. If the teacher's competence is low then their students would become a generation with poor quality [10]. So that it cannot be avoided that the education quality and the graduates often be seen as it depends on the teacher's role in managing the teaching components used in the process of teaching and learning, which is the responsibility of the school.

\section{CONCLUSION AND SUGGESTION}

The research concluded the quality education in terms of the school's principal leadership and teacher performance variable influenced the education quality.

Based on the conclusions above, it was expected to the school principals and education authorities to facilitate and encourage schools to pay attention to school leadership and teacher performance with the aspects that could improve the education quality.

\section{REFERENCES}

[1] EFA Global Monitoring Report, Education for All, The Quality Imperative. France, UNESCO Publishing, 2005.

[2] [2] B. Hayat dan Y. Suhendra, Benchmark Internasional Mutu Pendidikan. Jakarta, Bumi Aksara, 2010.

[3] [3] Keeves, J.P, National examinations: design, procedures and reporting. Paris, UNESCO, International Institute for Educational Planning, 1994.

[4] [4] Grounlund dan Linn, Measurement and evaluation in teaching. Sixth Edition. New York: Macmillan Publishing Company, 1990.

[5] [5] Nitko, Anthony J, Educational Assessment of Students, Second Edition. Ohio, Merrill an imprint of Prentice Hall Englewood Cliffs, 1996.

[6] [6] Townsend \& Butterworth, Your Child's Sholl. New York, A Plime Book, 1992.

[7] [7] E. Mulyasa, Menjadi Kepala Sekolah Profesional. Bandung, PT Remaja Rosda karya, 2007.

[8] [8] Rohiat, Manajemen Sekolah (Teori Dasar dan Praktik dilengkapi dengan contoh Rencana Strategik dan Operasional). Bandung, Refika Aditama, 2010.

[9] [9] M. Hasibuan, Organisasi dan Motivasi. Jakarta, BumiAksara, 2001.

[10] [10] J. Musfah, Peningkatan Kompetensi Guru Melalui Pelatihan dan Sumber Belajar Teori dan Praktik. Jakarta, Kencana, 2011. 